\title{
Does Soil Disturbance Affect Soil Phosphorus Fractions?
}

\author{
Yonathan D. Redel ${ }^{1,2}$, Rudolf Schulz ${ }^{1}$, Torsten Müller ${ }^{1}$ \\ ${ }^{1}$ University of Hohenheim, Institute of Crop Science, Fertilisation and Soil Matter Dynamics (340i), Stuttgart, Germany; ${ }^{2}$ Scientific \\ and Technological Bioresource Nucleus (Bioren-UFRO), Universidad de La Frontera, Temuco, Chile. \\ Email: yonathan.redel@ufrontera.cl
}

Received August $1^{\text {st }}, 2013$; revised September $1^{\text {st }}, 2013$; accepted September $8^{\text {th }}, 2013$

Copyright (C) 2013 Yonathan D. Redel et al. This is an open access article distributed under the Creative Commons Attribution License, which permits unrestricted use, distribution, and reproduction in any medium, provided the original work is properly cited.

\begin{abstract}
Increased turnover of organic matter as a result of soil disturbance (e.g. by soil tillage) is described in principle, but the direct influence of soil disturbance on soil P turnover especially for organic farming systems has not been sufficiently proven. The objective of the study was to evaluate the short term effect of soil disturbance on different soil P fractions in a soil shaking experiment. Four soils were incubated for 10 days in the dark with three different disturbance treatments: 1) no disturbance, 2) overhead shaking for $2 \mathrm{~h}$ at the beginning of the experiment and 3) continuous overhead shaking at $5 \mathrm{r}$. p. m. The four investigated soils were: 1) a silty loam soil with long term bio-compost application and 2) the corresponding soil without bio-compost application, 3) a long-term organically managed clay loam soil and 4) a clay loam soil with long time application of pig manure, all not and from Baden-Württemberg, Germany. We determined $\mathrm{NaHCO}_{3}-, \mathrm{NaOH}$ - and $\mathrm{H}_{2} \mathrm{SO}_{4}$-extractable inorganic and organic $\mathrm{P}$ fractions $\left(\mathrm{P}_{\mathrm{i}}\right.$ and $\mathrm{P}_{\mathrm{o}}$, resp.) in a sequential extraction. Furthermore, the potentially plant available $\mathrm{P}$ as Calcium-acetate-lactate-extractable $\mathrm{P}(\mathrm{CAL}-\mathrm{P})$ and $\mathrm{P}$ extractable by electro-ultra-filtration (EUF-P), and aqua regia extractable total $\mathrm{P}\left(\mathrm{P}_{\mathrm{T}}\right)$ were determined. Furthermore, we determined microbial biomass carbon (MBC), nitrogen (MBN) and phosphorus (MBP), and acid phosphatase activity in soil. The organically managed soil had the highest $\mathrm{P}_{\mathrm{T}}$ contents $\left(1300 \mathrm{mg} \cdot \mathrm{kg}^{-1}\right)$. The soil with pig manure application had the smallest potentially labile $\mathrm{P}$ fractions $\left(\mathrm{NaHCO}_{3}-\mathrm{P}_{\mathrm{i}}\right.$ and $-\mathrm{P}_{\mathrm{o}}$ and $\left.\mathrm{NaOH}-\mathrm{P}_{\mathrm{i}}\right)$. The ecologically managed soil had the biggest organic $\mathrm{P}$ fractions (114 mg $\cdot \mathrm{kg}^{-1} \mathrm{NaHCO}_{3}-\mathrm{P}_{\mathrm{o}}$ and $463 \mathrm{mg} \cdot \mathrm{kg}^{-1} \mathrm{NaOH}-\mathrm{P}_{\mathrm{o}}$ ), but, this soil was the lowest in CAL-P $\left(5 \mathrm{mg} \mathrm{kg}^{-1}\right)$. Short term soil disturbance had effects on labile organic $\mathrm{P}$ fractions of two of the four analyzed soils, but inorganic $\mathrm{P}$ was rather unaffected. In the compost amended $\mathrm{COMP}(+)$ soil, there was an incorporation of $\mathrm{P}$ from the less available NaOH-P fractions into the more available $\mathrm{NaHCO}_{3}-\mathrm{P}_{\mathrm{o}}$ fraction. However, if taking all investigated soils and treatments into account, the effects of soil disturbance were limited and not consistent.
\end{abstract}

Keywords: Phosphorus Fractions; Soil Disturbance; Microbial Phosphorus; Organic Phosphorus; Microbial Nitrogen; Acid Phosphatase Activity

\section{Introduction}

Investigating nutrient mobilization and immobilization as a result of soil tillage, it has to be distinguished between long term and short term effects [1]. Long term effects include changes in organic matter and nutrient distribution as well as organic matter and nutrient turnover within the soil profile after conversion from highly intensive to less intensive tillage systems, e.g. from ploughing to no-till, and vice versa. Many investigations are published on this subject including the effect of nutrient restratification [2-8]. In contrast to these investigations, this study focused on short term effects, i.e. the direct influence of soil disturbance on soil $\mathrm{P}$ turnover.

Increased turnover of organic matter as an immediate result of soil disturbance is described in principle $[9,10]$.
Aggregate crushing usually has positive effects on $\mathrm{C}$ and $\mathrm{N}$ mineralization as summarized in the review presented by [11]. $\mathrm{N}$ mobilization by soil disturbance and tillage is well documented in literature. An influence of soil tillage on $\mathrm{N}$ availability was postulated by [12] after comparison of measured and model simulated values. An influence of soil tillage intensity on $\mathrm{N}$ mineralization was reported by other authors (e.g. $[13,14])$. A considerable influence of different intensities of simple soil mixing on the adenylate energy charge during incubation for eight days at $25^{\circ} \mathrm{C}$ was reported by [9]. The energy level experienced by soils during a typical cultivation operation by repeated dropping of defined weight from a defined height on a soil core was imitated by [15]. The authors found a clear positive effect on soil $\mathrm{CO}_{2}$ evolution during the first 
hours following this treatment which was negatively correlated with the total soil $\mathrm{C}$ content. This loss of $\mathrm{C}$ by an increment of microbial activity as measured by soil respiration can be due to the fact that tillage/disturbance can open up pores, thus exposing previously protected soil organic matter to the attack by microorganisms [16].

Most investigations focusing on the effect of soil disturbance/tillage on soil $\mathrm{P}$ refer to long term field experiments with combined effects of fertilization and tillage. Soil disturbance enhances $\mathrm{P}$ allocation in inorganic fractions due to mineralization [17] whereas no tillage promotes an increase of enzymatic activities including acid phosphatase [18] and a nutrient stratification [7,8], showing more $\mathrm{P}$ fertilization placement effects rather than tillage effects. Other researches indicate that an adequate tillage can prevent topsoil $\mathrm{P}$ accumulation and $\mathrm{P}$ losses by erosion, but too heavy tillage enhances leaching of $P$ in particulate $P$ forms $[19,20]$. In contrast to $\mathrm{C}$ and $\mathrm{N}$, however, no detailed knowledge exists about $\mathrm{P}$ mobilization by soil disturbance and tillage in the short term, and in particular considering organically and longterm compost managed soils.

In organic farming, compost and manure are important sources as P fertilizers. Compost/manure added to soil can enhance the availability of phosphorus through the direct release of $P$ from the compost or indirectly through the release of humic acids to the soil. Humic substances can promote release of $\mathrm{P}$ by complexing $\mathrm{Fe}$ and $\mathrm{Al}$ derived from $\mathrm{Fe}$ - and $\mathrm{Al}$-phosphates [21], and by the formation of $\mathrm{Ca}$-humates when reacting with $\mathrm{Ca}$-phosphates [22], both resulting in a release of the corresponding phosphate anions. Furthermore, organic farming promotes accumulation of organic matter, and this also leads to improved physical properties such as a lower bulk density with lower dry strength and increased friability [23]. Moreover, to organic farming currently higher levels of biological activity were associated [24]. However, a positive effect of soil tillage on soil nutrient availability was postulated especially for organic farming systems but was not sufficiently proven [25].

Chemical sequential extraction procedures are widely used to subdivide extractable soil $\mathrm{P}$ into inorganic $\left(\mathrm{P}_{\mathrm{i}}\right)$ and organic $\left(\mathrm{P}_{\mathrm{o}}\right)$ fractions differing in extractability [26, 27]. In this procedure, the inorganic pool extracted with $0.5 \mathrm{M}$ sodium bicarbonate is attributed mainly to being labile $P_{i}$ in the solid soil phase attached to crystalline surfaces [27]; moderately labile $P_{i}$ extracted with $0.1 \mathrm{M}$ $\mathrm{NaOH}$ comprises chemisorbed $\mathrm{P}_{\mathrm{i}}$ of lower plant-availability associated with amorphous and crystalline $\mathrm{Fe}$ and $\mathrm{Al}$ hydroxides [26]; and no labile primary Ca-bound $\mathrm{P}$ is extractable through $0.5 \mathrm{M} \mathrm{HCl}$ or $\mathrm{H}_{2} \mathrm{SO}_{4}$ [28]. Regarding organic fractions, easily mineralisable $\mathrm{NaHCO}_{3}-\mathrm{P}_{\mathrm{o}}$ and moderate labile $\mathrm{NaOH}-\mathrm{P}_{\mathrm{o}}$ comprise $\mathrm{P}$ linked to organic matter $[28,29]$. The non-extractable recalcitrant $P_{i}$ and $P_{o}$ comprise residual $\mathrm{P}$ of very low availability [30]. Microbial $\mathrm{P}$ is extracted within or besides sequential fractionation procedure after soil fumigation by $\mathrm{CHCl}_{3}$ fractionation and $\mathrm{NaHCO}_{3}$ extraction [31].

The objective of this study was to evaluate the short term effect of soil disturbance on different soil P fractions in a soil shaking experiment. It was hypothesized that soil disturbance (here soil shaking) mobilizes soil P, eventually leading to a redistribution of soil $\mathrm{P}$ towards more labile fractions.

\section{Materials and Methods}

\subsection{Soils and Compost}

Four soils were sampled at $0-30 \mathrm{~cm}$ depth from three different sites in Baden-Württemberg, Southern Germany at November 2009. Five sub-samples of each $20 \mathrm{~cm}$ diameter core were taken across the sampling sites $(20 \times$ $50 \mathrm{~m})$.

1) COMP(-): Silty loam soil (Loess derived Luvisol) taken from a long term (since 1997) compost fertilization experiment at the experimental farm "Heidfeldhof", belonging to the University of Hohenheim, located in the south-west of Stuttgart, Germany (48 43'00"N; $\left.9^{\circ} 11^{\prime} 40^{\prime \prime} \mathrm{E}\right)$, control variant without compost application.

2) $\operatorname{COMP}(+)$ : The same soil as $\operatorname{COMP}(-)$ but with high annual application rates of mature bio-compost corresponding to $400 \mathrm{~kg}$ total $\mathrm{N} \mathrm{ha}^{-1} \mathrm{a}^{-1}$ or approx. $40 \mathrm{t} \mathrm{DM}$ $\mathrm{ha}^{-1} \mathrm{a}^{-1}$. The compost derived mainly from kitchen waste and garden plant residues digested in a central compost plant. The compost contained around $4500 \mathrm{mg} \mathrm{P} \mathrm{kg}^{-1}$ $\mathrm{DM}$, with an average of $1566 \mathrm{mg} \cdot \mathrm{kg}^{-1} \mathrm{NaHCO}_{3}-\mathrm{P}, 342$ $\mathrm{mg} \cdot \mathrm{kg}^{-1} \mathrm{NaOH}-\mathrm{P}$ and $2472 \mathrm{mg} \cdot \mathrm{kg}^{-1} \mathrm{H}_{2} \mathrm{SO}_{4}-\mathrm{P}$, and $84 \%$ $\mathrm{P}_{\mathrm{i}}$ of the total P (average of years 2000 and 2008).

3) ECO: Clay loam soil (Regosol) from a site under long term bio-dynamic farming (ECO) according to the regulations of the German "Demeter" association; taken $2 \mathrm{~km}$ south of Rosenfeld, Germany $\left(48^{\circ} 16^{\prime} 32^{\prime \prime} \mathrm{N}\right.$; $\left.8^{\circ} 43^{\prime} 00^{\prime \prime} \mathrm{E}\right)$.

4) MAN: Clay loam soil (Gleyic Vertisol) with long term liquid pig manure application from a site at the experimental farm of the Agricultural Technology Centre (LTZ) in Karlsruhe-Durlach, Germany $\left(49^{\circ} 14^{\prime} 25^{\prime \prime} \mathrm{N}\right.$; 9॰59'43"E).

All soils were sieved $(<2 \mathrm{~mm} \varnothing)$, adjusted to approx. $50 \%$ of max water holding capacity and stored at $4^{\circ} \mathrm{C}$ until the experiment started. Three treatments were carried out in five replicates during 10 -days at $15^{\circ} \mathrm{C}$ in the dark: 1) control soil with no disturbance during incubation (T-0), 2) soil disturbance by shaking during the first two hours of incubation on an overhead multi-axle rotating shaker at 5 r. p. m. (T-1), 3) soil disturbance by continuous shaking of the soil during 10 days on an overhead multi-axle rotating shaker at 5 r. p. m. (T-2). 
The shaking treatments energy can be estimated from the size of the bottles $(250 \mathrm{~mL})$, and the number of rotations for each treatment. Considering a bottle size of approx. $10 \mathrm{~cm}$ height, 600 rotations in the $2 \mathrm{~h}$ and 72,000 in the $10 \mathrm{~d}$ treatment, the energy applied was according the formula $\mathrm{K}=m * g * h$ (K: kinetic energy, $m$ : weight; $g$ : gravity acceleration $=9.8 \mathrm{~m} \cdot \mathrm{s}^{-2}$ and $h$ : height) of 294 $\mathrm{J} \cdot \mathrm{kg}^{-1}$ and $35,280 \mathrm{~J} \cdot \mathrm{kg}^{-1}$, respectively. The $2 \mathrm{~h}$ treatment can be compared to the energy of $150 \mathrm{~J} \cdot \mathrm{kg}^{-1}$ of typical soil cultivation $[15,32]$, but the $10 \mathrm{~d}$ treatment energy input was several times higher than for average soil cultivation.

For all treatments, $50 \mathrm{~g}$ moist soil was incubated in $250 \mathrm{~mL}$ polyethylene bottles. After ten days, soils in all bottles were homogenized and further processed as described below. From the years 2000 and 2008 of the long term compost experiment, compost samples were available and subject to $\mathrm{P}$ fractionation in the same way as the soil samples (see below).

\subsection{Soil and Compost Analyses}

Soil pH was determined in $0.01 \mathrm{M} \mathrm{CaCl}_{2}$ in a soil- solution relation of $1 \mathrm{~g}$ : $2.5 \mathrm{~mL}$. Organic $\mathrm{C}\left(\mathrm{C}_{\text {org }}\right)$ and total $\mathrm{N}$ where measured with an $\mathrm{C}-\mathrm{N}$-auto-analyzer ("Vario MAX CN" type, "Elementar" Company). Microbial biomass $\mathrm{C}$ and $\mathrm{N}$ (MBC and $\mathrm{MBN}$, respectively) were estimated by fumigation-extraction [33]. Briefly, one 25 $\mathrm{g}$ portion soil was fumigated for $24 \mathrm{~h}$ at $25^{\circ} \mathrm{C}$ with ethanol-free $\mathrm{CHCl}_{3}$. Following fumigant removal, the soil was extracted with $100 \mathrm{~mL} 0.5 \mathrm{M} \mathrm{K}_{2} \mathrm{SO}_{4}$ by $30 \mathrm{~min}$ horizontal shaking at $200 \mathrm{r}$. m. p. and filtered yielding a clear filtrate. Another non-fumigated $25 \mathrm{~g}$ portion of soil was extracted similarly at the time fumigation commenced. The extracts were frozen until analyses for total $\mathrm{C}$ and $\mathrm{N}$ concentrations on a TOC/TIC analyzer (Multi N/C 2100, Analytik Jena, Germany). Microbial biomass C (MBC) was calculated as follows: $\mathrm{MBC}=\mathrm{EC} / \mathrm{k}_{\mathrm{EC}}$; where $\mathrm{EC}=$ (organic $\mathrm{C}$ extracted from fumigated soils)-(organic $\mathrm{C}$ extracted from non-fumigated soils) and $\mathrm{k}_{\mathrm{EC}}=0.45[34$, 35]. Microbial biomass $\mathrm{N}(\mathrm{MBN})$ was calculated the same way but using $\mathrm{k}_{\mathrm{EN}}=0.54$ [36].

Phosphorus in soils and compost was fractionated according to a modified "Hedley" fractionation method [26, 37]. Briefly, $0.5 \mathrm{~g}$ soil were extracted with $0.5 \mathrm{M} \mathrm{Na}-$ $\mathrm{HCO}_{3}$ followed by extraction with $0.1 \mathrm{M} \mathrm{NaOH}$. Finally, the remaining soil was extracted with $0.5 \mathrm{M} \mathrm{H}_{2} \mathrm{SO}_{4}$. The "inorganic" molybdate reactive phosphorous $\left(\mathrm{P}_{\mathrm{i}}\right)$ in all extracts was measured by the method of [38] at $700 \mathrm{~nm}$ and $\mathrm{pH} 5.0$ spectrophotometrically (Hitachi U-3300), whereas "organic" phosphorous $\left(\mathrm{P}_{\mathrm{o}}\right)$ in all extracts was calculated as the difference between total $\mathrm{P}$ and $\mathrm{P}_{\mathrm{i}}$. Thus, this fractionation procedure yielded six different analytical fractions: $\mathrm{NaHCO}_{3}-\mathrm{P}_{\mathrm{i}}, \mathrm{NaHCO}_{3}-\mathrm{P}_{\mathrm{o}}, \mathrm{NaOH}-\mathrm{P}_{\mathrm{i}}$, $\mathrm{NaOH}-\mathrm{P}_{\mathrm{o}}, \mathrm{H}_{2} \mathrm{SO}_{4}-\mathrm{P}_{\mathrm{i}}$ and $\mathrm{H}_{2} \mathrm{SO}_{4}-\mathrm{P}_{\mathrm{o}}$. Total $\mathrm{P}\left(\mathrm{P}_{\mathrm{T}}\right)$ in soil samples were extracted with aqua regia $\left(1: 3 \mathrm{HNO}_{3}\right.$ and $\mathrm{HCl}$ ) extraction) and determined with ICP-OES ("Vista Pro" type, "Varian" company) [39].

Microbial biomass P (MBP) was estimated by Chloroform Fumigation Extraction [31]. Fumigation was done as described for microbial $\mathrm{C}$. Following fumigant removal, the soil was extracted with $0.5 \mathrm{M} \mathrm{NaHCO}_{3}$ by 30 min. horizontal shaking at 200 r. p. m. and filtered. Nonfumigated soil was treated similarly, except that the desiccator contained no $\mathrm{CHCl}_{3}$, and was not evacuated. Inorganic $\mathrm{P}$ was analyzed in aliquots of the extracts by the ammonium molybdate-ascorbic acid method described by [38]. A spike of $\mathrm{KH}_{2} \mathrm{PO}_{4}$ equivalent to $25 \mu \mathrm{g} \mathrm{P} \mathrm{g}$ soil was used to correct for $\mathrm{P}_{\mathrm{i}}$ fixation for each soil during the $\mathrm{NaHCO}_{3}$ extraction. Biomass $\mathrm{P}$ was calculated $\mathrm{MBP}=\mathrm{EP} / \mathrm{k}_{\mathrm{EP}} /$ recovery, where EP is the difference between $\mathrm{NaHCO}_{3}-\mathrm{P}_{\mathrm{i}}$ extracted from fumigated and nonfumigated soil, and recovery is the recovering factor obtained for correct $\mathrm{P}_{\mathrm{i}}$ fixation mentioned above [31,40] and $\mathrm{k}_{\mathrm{EP}}$ is 0.4 [41].

Plant available $\mathrm{P}$ was characterized by Calcium Acetate Lactate (CAL) extraction [42]. $5 \mathrm{~g}$ soil was extracted by shaking for $90 \mathrm{~min}$ with $100 \mathrm{ml}$ of a $0.05 \mathrm{M} \mathrm{Ca}$ acetate- $0.05 \mathrm{M}$ Ca lactate- $0.3 \mathrm{M} \mathrm{CH}_{3} \mathrm{COOH} \mathrm{pH} 4.1$ solution followed by filtration. $\mathrm{P}$ in the extract was determined colorimetrically by using ammonium molybdate reduced with ascorbic acid and Zn-chlorhydrate and followed by spectrophotometrical measurement of the absorbance at $480 \mathrm{~nm}$ (Hitachi U-3300).

Acid phosphatase (orthophosphoric-monoester phosphomonoesterase) activity (P-ase) was determined by the p-nitrophenyl phosphate method with modifications, as described by $[43,44]$. Briefly, soil samples (1 g) were incubated with $1 \mathrm{~mL} 50 \mathrm{mM}$ p-nitrophenol phosphate and $4 \mathrm{~mL} 0.1 \mathrm{M}$ tris buffer $\mathrm{pH} 5.5$ for $1 \mathrm{~h}$ at $20^{\circ} \mathrm{C}$. At the end of the incubation period, $1 \mathrm{~mL} 0.5 \mathrm{M} \mathrm{CaCl}_{2}$ was added, and the solution was quickly filtered. Then, the filtrate was treated with $4 \mathrm{~mL} 0.5 \mathrm{M} \mathrm{NaOH}$. Samples were homogenized and centrifuged at $2500 \mathrm{~g}$ for $10 \mathrm{~min}$. $p$-nitrophenol released was determined spectrophotometrically by measuring the absorbance of the supernatant at $400 \mathrm{~nm}$ (Hitachi U-3300).

Soil $\mathrm{P}$ as determined by electro ultrafiltration (EUF) was extracted according $[45,46]$. The first $\mathrm{P}$ fraction (P-1) was collected the first $30 \mathrm{~min}$. at $20^{\circ} \mathrm{C}$ with an electric current of max. $200 \mathrm{~V}$ and $15 \mathrm{~mA}$; this fraction is assumed to contain available $\mathrm{P}$. The second $\mathrm{P}$ fraction $(\mathrm{P}-2)$ was collected during minutes 30 and 35 at $80^{\circ} \mathrm{C}$ with an electric current of max. $400 \mathrm{~V}$ and $150 \mathrm{~mA}$; this fraction is assumed to contain labile P [45].

\subsection{Statistics}

Results of the soil analyses are presented as mean values of five repetitions. The data were subjected to analyses of 
variance using the ANOVA procedures of the SAS/ STAT, version 6 [47]. Data were arcsine transformed to meet requirements of normality if needed and further compared by the Duncan's multiple range test. Statistical significance was determined at $\mathrm{P} \leq 0.05$. Pearson correlations and principle component analysis (PCA) were performed using SAS/STAT, version 6 [47].

\section{Results}

Several years of compost addition $(\mathrm{COMP}(+))$ increased concentrations of available CAL-P and also $\mathrm{P}$ determined by electro-ultrafiltration (P1(EUF) and P2(EUF)) compared to COMP(-) (Table 1). However, the increase of $\mathrm{P}_{\mathrm{t}}$ by $130 \mathrm{mg}(\mathrm{kg} \text { soil })^{-1}$ did not affect most of the sequential P-Fractions. Only $\mathrm{H}_{2} \mathrm{SO}_{4}-\mathrm{P}_{\mathrm{i}}$ was increased by $180 \mathrm{mg} \mathrm{kg} \mathrm{soil}{ }^{-1} \cdot \mathrm{H}_{2} \mathrm{SO}_{4}-\mathrm{P}_{\mathrm{o}}$ was extremely small and only detectable in the COMP(-) soil (not indicated in Table 1). Furthermore, compost addition enhanced microbial biomass (MBC and MBN) almost two-fold (Table 1).

The other two soils, ECO and MAN, were not included in the statistical analysis as they have different parental materials and textures and soils differed consid-

Table 1. Soil quality indicators and phosphorus fractions in the original soils.

\begin{tabular}{|c|c|c|c|c|c|}
\hline Soil & unit & COMP (-) & COMP (+) & ECO & MAN \\
\hline $\mathrm{pH}\left(\mathrm{CaCl}_{2}\right)$ & & $6.46 \mathbf{b}$ & $7.22 \mathbf{a}$ & 6.22 & 7.50 \\
\hline $\mathrm{N}_{\mathrm{T}}$ & $\mathrm{mg} \cdot \mathrm{g}^{-1}$ & 1.26 & 2.12 & 3.76 & 2.52 \\
\hline $\mathrm{C}_{\mathrm{org}} / \mathrm{N}_{\mathrm{T}}$ & & 7.7 & 8.3 & 9.6 & 9.6 \\
\hline $\mathrm{P}_{\mathrm{T}}$ & $\mathrm{mg} \cdot \mathrm{kg}^{-1}$ & $789 \mathbf{b}$ & $922 \mathbf{a}$ & 1300 & 1060 \\
\hline CAL-P & $\mathrm{mg} \cdot \mathrm{kg}^{-1}$ & $67 \mathbf{b}$ & $144 \mathbf{a}$ & 5 & 23 \\
\hline P1 (EUF) & $\mathrm{mg} \cdot \mathrm{kg}^{-1}$ & $32.4 \mathbf{b}$ & $48.6 \mathbf{a}$ & 11.1 & 9.8 \\
\hline P2 (EUF) & $\mathrm{mg} \cdot \mathrm{kg}^{-1}$ & $9.3 \mathbf{b}$ & $15.1 \mathbf{a}$ & 4.1 & 3.5 \\
\hline $\mathrm{NaHCO}_{3}-\mathrm{P}_{\mathrm{i}}$ & $\mathrm{mg} \cdot \mathrm{kg}^{-1}$ & 185 & 185 & 49 & 40 \\
\hline $\mathrm{NaHCO}_{3}-\mathrm{P}_{\mathrm{o}}$ & $\mathrm{mg} \cdot \mathrm{kg}^{-1}$ & 51 & 68 & 115 & 91 \\
\hline $\mathrm{NaOH}-\mathrm{P}_{\mathrm{i}}$ & $\mathrm{mg} \cdot \mathrm{kg}^{-1}$ & 197 & 186 & 143 & 50 \\
\hline $\mathrm{NaOH}-\mathrm{P}_{\mathrm{o}}$ & $\mathrm{mg} \cdot \mathrm{kg}^{-1}$ & 112 & 79 & 464 & 176 \\
\hline $\mathrm{H}_{2} \mathrm{SO}_{4}-\mathrm{P}_{\mathrm{i}}$ & $\mathrm{mg} \cdot \mathrm{kg}^{-1}$ & $212 \mathbf{b}$ & $392 \mathbf{a}$ & 316 & 370 \\
\hline \multicolumn{6}{|l|}{ Microbial biomass } \\
\hline $\mathrm{MBC}$ & $\mathrm{mg} \cdot \mathrm{kg}^{-1}$ & $148 \mathbf{b}$ & $241 \mathbf{a}$ & 589 & 463 \\
\hline $\mathrm{MBN}$ & $\mathrm{mg} \cdot \mathrm{kg}^{-1}$ & $20 \mathbf{b}$ & $40 \mathbf{a}$ & 63 & 52 \\
\hline $\mathrm{MBN} / \mathrm{N}_{\mathrm{T}}$ & $\%$ & 11.7 & 12.4 & 5.5 & 5.3 \\
\hline $\mathrm{MBP} / \mathrm{P}_{\mathrm{T}}$ & $\%$ & 2.1 & 1.9 & 1.7 & 2.1 \\
\hline Molar C:N:P & & $20: 2: 1$ & $57: 8: 1$ & $304: 28: 1$ & $399: 38: 1$ \\
\hline Acid P-ase & $\operatorname{mg~PNF~kg}{ }^{-1} \cdot \mathrm{h}^{-1}$ & $105 \mathbf{b}$ & $441 \mathbf{a}$ & 946 & 376 \\
\hline
\end{tabular}

COMP(-): Silty loam soil without compost application; $\operatorname{COMP}(+)$ : Silty loam soil with long term compost application; ECO: Clay loam soil under long term bio-dynamic farming; MAN: Clay loam soil with long term liquid pig manure application; $\mathrm{C}_{\text {org }}$ : organic carbon; $\mathrm{N}$ : total $\mathrm{N}$, $\mathrm{P}_{\mathrm{T}}$ : total $\mathrm{P}$ extractable with aqua regia. CAL-P: extractable with calcium acetate lactate solution; P1(EUF): P extractable by electro-ultra-filtration, $1^{\text {st }}$. fraction; P2(EUF): P extractable by electro-ultra-filtration, $2^{\text {nd }}$. fraction; $\mathrm{NaHCO}_{3}-\mathrm{P}_{\mathrm{i}}$ : inorganic $\mathrm{P}$ extractable with $\mathrm{NaHCO}_{3} ; \mathrm{NaHCO}_{3}-\mathrm{P}_{\mathrm{o}}$ : organic $\mathrm{P}$ extractable with $\mathrm{NaHCO}_{3} ; \mathrm{NaOH}_{\mathrm{P}}$ : inorganic $\mathrm{P}$ extractable with $\mathrm{NaOH} ; \mathrm{NaOH}-\mathrm{P}_{\mathrm{o}}$ : organic $\mathrm{P}$ extractable with $\mathrm{NaOH} ; \mathrm{H}_{2} \mathrm{SO}_{4}-\mathrm{P}_{\mathrm{i}}$ : inorganic $\mathrm{P}$ extractable with $\mathrm{H}_{2} \mathrm{SO}_{4}$; $\mathrm{MBC}$ : microbial biomass C; $\mathrm{MBN}$ : microbial biomass N; MBP: microbial biomass P; acid P-ase: acid phosphatase activity; PNF: $p$-nitrophenol). Different letters in the same P fraction show significant differences determined by $t$ test $(\mathrm{P}<0.05$, MAN and ECO soil were not included). 
erably in the determined $\mathrm{P}$ fractions. In general, ECO and MAN contain more $\mathrm{P}_{\mathrm{o}}$ and less $\mathrm{P}_{\mathrm{i}}$ in both $\mathrm{NaHCO}_{3}$ - and $\mathrm{NaOH}$-extractable fractions compared to $\mathrm{COMP}(-)$ and $\mathrm{COMP}(+)$ soils. The ECO soil had the highest concentration of $\mathrm{P}_{\mathrm{T}}$ and of the $\mathrm{P}_{\mathrm{o}}$ fractions compared with the other soils. Furthermore, ECO and MAN have in general higher microbial biomasses and $\mathrm{P}$-ase activities than $\mathrm{COMP}(-)$ and $\mathrm{COMP}(+)$ soils (Table 1). $\mathrm{MBC} / \mathrm{C}_{\text {org }}$, $\mathrm{MBN} / \mathrm{N}_{\mathrm{T}}$ and $\mathrm{MBP} / \mathrm{P}_{\mathrm{T}}$ ratios were fairly constant among all soils, except $\mathrm{MBN} / \mathrm{N}_{\mathrm{T}}$ that was almost twice as high in ECO and MAN compared to $\operatorname{COMP}(-)$ and $\operatorname{COMP}(+)$ soils (Table 1).

Significant effects of the soil shaking treatments on the investigated variables were limited and not consistent (Table 2). In the $\mathrm{COMP}(+)$ soil, $\mathrm{NaOH}-\mathrm{P}_{\mathrm{o}}$ decreased while $\mathrm{NaHCO}_{3}-\mathrm{P}_{\mathrm{o}}, \mathrm{H}_{2} \mathrm{SO}_{4}-\mathrm{P}_{\mathrm{i}}(2 \mathrm{~h}$ shaking only) and $\mathrm{MBN}$ (10 d shaking only) increased. In the ECO soil, $\mathrm{H}_{2} \mathrm{SO}_{4}-\mathrm{P}_{\mathrm{i}}$ and CAL-P increased after $10 \mathrm{~d}$ shaking. Only in the ECO soil, acid P-ase activity increased after $10 \mathrm{~d}$ shaking. In the $\mathrm{MAN}$ soil, $\mathrm{NaHCO}_{3}-\mathrm{P}_{\mathrm{i}}$ decreased $(10 \mathrm{~d}$ shaking only) while $\mathrm{NaHCO}_{3}-\mathrm{P}_{\mathrm{o}}$ increased.
Furthermore, both shaking treatments led to a decrease of soil microbial biomass (significant for $\mathrm{MBC}$ and MBN). The COMP(-) soil was unaffected by soil shaking, except an increase of MBP after $10 \mathrm{~d}$ shaking.

In general, $\mathrm{NaHCO}_{3}-\mathrm{P}_{\mathrm{i}}$ is correlated with CAL-P and MBP (Table 3). $\mathrm{NaHCO}_{3}-\mathrm{P}_{\mathrm{o}}$ is positively correlated with $\mathrm{NaOH}-\mathrm{P}_{\mathrm{o}}$ and $\mathrm{P}$-ase and $\mathrm{MBC}$ and $\mathrm{MBN}$, but negatively with CAL-P and MBP. The $\mathrm{H}_{2} \mathrm{SO}_{4}-\mathrm{P}_{\mathrm{i}}$ fraction did not correlate with any other parameter. $\mathrm{P}$-ase correlated positively with microbial elements, negatively with available $\mathrm{P}_{\mathrm{i}}$ but positively with $\mathrm{P}_{\mathrm{o}}$ forms.

PCA analysis (Figure 1) shows that organic C, microbial C (MBC) and N (MBN), P-ase, total $\mathrm{C}$ and $\mathrm{N}$, and $\mathrm{P}_{\mathrm{o}}$ $\left(\mathrm{NaOH}\right.$ and $\mathrm{NaHCO}_{3}$ ) were strongly related to $\mathrm{PC} 1$, whereas available and labile $\mathrm{P}_{i}$ fractions were negatively related to $\mathrm{PC} 1$ and positively to $\mathrm{PC} 2$. No labile $\mathrm{P}_{\mathrm{i}}$ and $\mathrm{pH}$ were dispersed on the plot.

As indicated in Figure 2, A correlation could be detected between CAL-P (as an indicator of plant available $\mathrm{P}$ ) and the $\mathrm{NaHCO}_{3}-\mathrm{P}_{\mathrm{i}}$ fraction (considered as labile $\mathrm{P}_{\mathrm{i}}$ ). However, data were strongly clustered due to the four

Table 2. Phosphorus fractions and microbial biomass variations after the disturbance experiment.

\begin{tabular}{|c|c|c|c|c|c|c|c|c|c|c|c|c|}
\hline \multirow{3}{*}{$\begin{array}{c}\text { Soil } \\
\text { Treatment } \\
\text { unit }\end{array}$} & \multicolumn{3}{|c|}{-------COMP(-)------ } & \multicolumn{3}{|c|}{------COMP(+)------ } & \multicolumn{3}{|c|}{--------ECO-------- } & \multicolumn{3}{|c|}{--------MAN------- } \\
\hline & \multirow{2}{*}{$\begin{array}{c}\text { no } \\
\text { shaking } \\
\mathrm{mg} \cdot \mathrm{kg}^{-1}\end{array}$} & $2 \mathrm{~h}$ & $10 \mathrm{~d}$ & $\begin{array}{c}\text { no } \\
\text { shaking }\end{array}$ & $2 \mathrm{~h}$ & $10 \mathrm{~d}$ & $\begin{array}{c}\text { no } \\
\text { shaking }\end{array}$ & $2 \mathrm{~h}$ & $10 \mathrm{~d}$ & $\begin{array}{c}\text { no } \\
\text { shaking }\end{array}$ & $2 \mathrm{~h}$ & $10 \mathrm{~d}$ \\
\hline & & \multicolumn{2}{|c|}{ \% change } & $\mathrm{mg} \cdot \mathrm{kg}^{-1}$ & \multicolumn{2}{|c|}{$\%$ change } & $\mathrm{mg} \cdot \mathrm{kg}^{-1}$ & \multicolumn{2}{|c|}{$\%$ change } & $\mathrm{mg} \cdot \mathrm{kg}^{-1}$ & \multicolumn{2}{|c|}{$\%$ change } \\
\hline Total P & 840 & 1 & 2 & 1005 & -5 & -6 & 1415 & 4 & 1 & 1076 & 8 & 1 \\
\hline CAL-P & 62 & -3 & -1 & 119 & 0 & 0 & 2 & 70 & $304^{*}$ & 4 & 0 & 36 \\
\hline \multicolumn{13}{|l|}{$P$ fractions } \\
\hline $\mathrm{NaHCO}_{3}-\mathrm{P}_{\mathrm{i}}$ & 156 & -5 & -2 & 208 & 2 & 6 & 35 & 15 & 0 & 23 & 9 & $-31^{*}$ \\
\hline $\mathrm{NaHCO}_{3}-\mathrm{P}_{\mathrm{o}}$ & 8 & 58 & -1 & 7 & $149^{*}$ & $235^{*}$ & 49 & 2 & -22 & 26 & $38^{*}$ & $45^{*}$ \\
\hline $\mathrm{NaOH}-\mathrm{P}_{\mathrm{i}}$ & 136 & -8 & 0 & 167 & 9 & -1 & 163 & -5 & -1 & 66 & 4 & 5 \\
\hline $\mathrm{NaOH}-\mathrm{P}_{\mathrm{o}}$ & 99 & -1 & 18 & 158 & $-74^{*}$ & $-69^{*}$ & 241 & 0 & -6 & 91 & -5 & 8 \\
\hline $\mathrm{H}_{2} \mathrm{SO}_{4}-\mathrm{P}_{\mathrm{i}}$ & 232 & -10 & 6 & 284 & $20^{*}$ & -5 & 222 & 31 & $35^{*}$ & 265 & 12 & -12 \\
\hline \multicolumn{13}{|c|}{ Microbial biomass } \\
\hline $\mathrm{MBC}$ & 148 & 23 & -24 & 171 & 57 & 58 & 442 & 43 & 17 & 480 & $-17^{*}$ & $-23^{*}$ \\
\hline $\mathrm{MBN}$ & 23 & -26 & -19 & 40 & -15 & $-23^{*}$ & 52 & 20 & 26 & 54 & $-48^{*}$ & $-37^{*}$ \\
\hline MBP & 37 & 3 & $44^{*}$ & 46 & 2 & 3 & 29 & -16 & 7 & 23 & -3 & -15 \\
\hline Molar C:N:P & $11: 1: 1$ & $11: 1: 1$ & $7: 1: 1$ & $10: 1: 1$ & $15: 2: 1$ & $15: 1: 1$ & $40: 4: 1$ & $68: 6: 1$ & $43: 5: 1$ & $55: 5: 1$ & $47: 3: 1$ & $49: 4: 1$ \\
\hline $\mathrm{MBP} / \mathrm{P}_{\mathrm{T}}(\%)$ & 4.4 & 2 & 41 & 4.6 & 7 & 10 & 2.0 & -13 & 6 & 2.1 & -10 & -16 \\
\hline Acid P-ase ${ }^{(1)}$ & 226 & 3 & 17 & 238 & -2 & -13 & 596 & 7 & $41^{*}$ & 307 & -13 & -2 \\
\hline
\end{tabular}

COMP(-): Silty loam soil without compost application; COMP(+): Silty loam soil with long term compost application; ECO: Clay loam soil under long term bio-dynamic farming; MAN: Clay loam soil with long term liquid pig manure application; $\mathrm{C}_{\text {org }}$ : organic carbon; $\mathrm{N}$ : total $\mathrm{N}$, $\mathrm{P}_{\mathrm{T}}$ : total $\mathrm{P}$ extractable with aqua regia. CAL-P: extractable with calcium acetate lactate solution; P1(EUF): P extractable by electro-ultra-filtration, $1^{\text {st }}$. fraction; P2(EUF): P extractable by electro-ultra-filtration, $2^{\text {nd }}$. fraction; $\mathrm{NaHCO}_{3}-\mathrm{P}_{\mathrm{i}}$ : inorganic $\mathrm{P}$ extractable with $\mathrm{NaHCO}_{3} ; \mathrm{NaHCO}_{3}-\mathrm{P}_{\mathrm{o}}$ : organic $\mathrm{P}$ extractable with $\mathrm{NaHCO}_{3} ; \mathrm{NaOH}_{\mathrm{P}}$ : inorganic $\mathrm{P}$ extractable with $\mathrm{NaOH} ; \mathrm{NaOH}-\mathrm{P}_{\mathrm{o}}$ : organic $\mathrm{P}$ extractable with $\mathrm{NaOH} ; \mathrm{H}_{2} \mathrm{SO}_{4}-\mathrm{P}_{\mathrm{i}}$ : inorganic $\mathrm{P}$ extractable with $\mathrm{H}_{2} \mathrm{SO}_{4}$; $\mathrm{MBC}$ : microbial biomass C; $\mathrm{MBN}$ : microbial biomass N; MBP: microbial biomass P; acid P-ase: acid phosphatase activity; PNF: $p$-nitrophenol). Different letters in the same P fraction show significant differences determined by $t$ test $(\mathrm{P}<0.05$, MAN and ECO soil were not included). 
Table 3. Pearson correlation table for soil phosphorus fractions and microbial biomass after incubation.

\begin{tabular}{|c|c|c|c|c|c|c|c|c|c|c|c|}
\hline & & 1 & 2 & 3 & 4 & 5 & 6 & 7 & 8 & 9 & 10 \\
\hline 1 & $\mathrm{NaHCO}_{3}-\mathrm{P}_{\mathrm{i}}$ & & & & & & & & & & \\
\hline 2 & $\mathrm{NaHCO}_{3}-\mathrm{P}_{\mathrm{o}}$ & -0.71 & & & & & & & & & \\
\hline 3 & $\mathrm{NaOH}-\mathrm{P}_{\mathrm{i}}$ & 0.57 & -0.12 & & & & & & & & \\
\hline 4 & $\mathrm{NaOH}-\mathrm{P}_{\mathrm{o}}$ & -0.48 & 0.56 & 0.28 & & & & & & & \\
\hline 5 & $\mathrm{H}_{2} \mathrm{SO}_{4}-\mathrm{P}_{\mathrm{i}}$ & 0.11 & 0.04 & 0.25 & -0.12 & & & & & & \\
\hline 6 & Total P & -0.67 & 0.81 & 0.10 & 0.75 & 0.26 & & & & & \\
\hline 7 & CAL-P & 0.97 & -0.65 & 0.64 & -0.44 & 0.18 & -0.59 & & & & \\
\hline 8 & $\mathrm{MBC}$ & -0.72 & 0.86 & -0.03 & 0.64 & 0.17 & 0.88 & -0.60 & & & \\
\hline 9 & $\mathrm{MBN}$ & -0.51 & 0.62 & 0.22 & 0.68 & 0.28 & 0.85 & -0.30 & 0.80 & & \\
\hline 10 & MBP & 0.77 & -0.57 & 0.53 & -0.31 & 0.14 & -0.54 & 0.71 & -0.63 & -0.36 & \\
\hline 11 & Acid P-ase $^{(1)}$ & -0.57 & 0.62 & 0.26 & 0.84 & 0.10 & 0.84 & -0.54 & 0.72 & 0.76 & -0.36 \\
\hline
\end{tabular}

Abbreviations: see Table 1. Bold numbers denotes significant correlations at $\mathrm{p}<0.05, \mathrm{n}=60$.

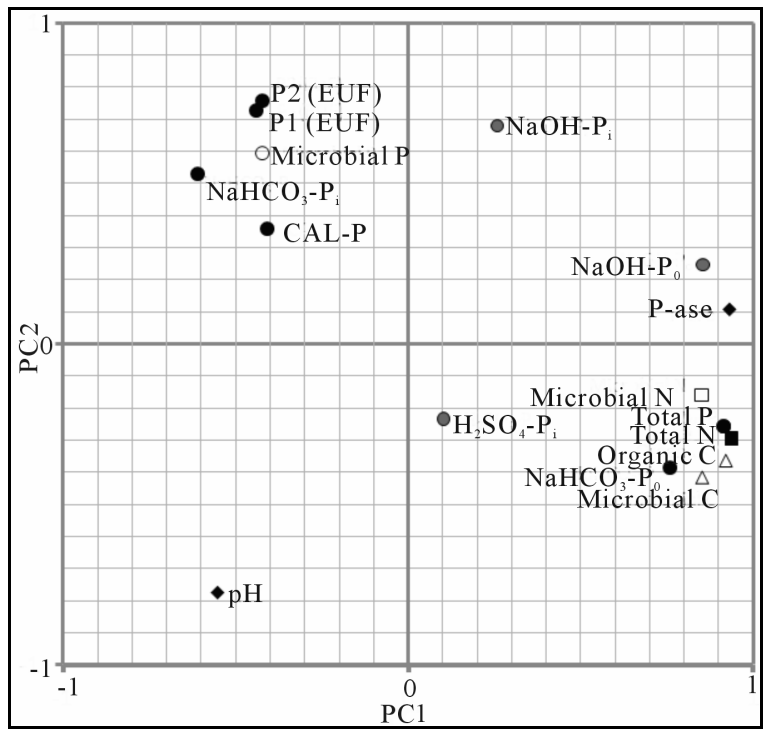

Figure 1. PCA analysis of incubated soils. Only the two principal components were considered. Abbreviations: see Table 1.

soils used in this investigation.

\section{Discussion}

The different soils had contrasting soil properties concerning $\mathrm{P}$ fractions. The high compost amendment resulted in a higher $\mathrm{H}_{2} \mathrm{SO}_{4}-\mathrm{P}_{\mathrm{i}}$ and, as a consequence, in a higher $\mathrm{P}_{\mathrm{T}}$ content. However, the other fractions were almost unaffected, except available CAL-P. It is reported that $\mathrm{P}$ derived from organic fertilizer can be found as $\mathrm{P}_{\mathrm{i}}$ after few hours [48], or as labile and recalcitrant $P_{o}$ after 56 ds in soil [49] and after 25 years [50] or 34 years [51]. However, how compost $\mathrm{P}$ is transformed after application may depends on the nature of the residues, soils, crop $\mathrm{P}$ uptake, management, climate and others factors. Under high yields, soil $\mathrm{P}_{\mathrm{o}}$ can be depleted [52] as well as available $\mathrm{P}$ [53]. High $\mathrm{P}_{\mathrm{i}}$ in compost could be responsible that large parts of $\mathrm{P}$ could be found in the $\mathrm{P}_{\mathrm{i}}$ but not in the $\mathrm{P}_{\mathrm{o}}$ fraction. Nevertheless, P-ase was four times higher in the COMP $(+)$ soil compared to COMP(-) soil. Thus, microbial activity might be responsible for high available $\mathrm{P}$ (CAL-P) in this soil.

CAL-P was relatively high in COMP(+) and COMP(-) soils considering the $\mathrm{P}$ classification of official extension services (optimal and elevated, respectively, [50]). CAL measurements resulted in 5 to more than 10 fold higher $\mathrm{P}$ concentrations for COMP soils compared to ECO and MAN. Same differences between the soils were visible for other fractions considered as easily available (EUF and $\mathrm{NaHCO}_{3}-\mathrm{P}_{\mathrm{i}}$ ), although, not to the same extent. Although CAL-P and $\mathrm{NaHCO}_{3}-\mathrm{P}_{\mathrm{i}}$ were closely correlated, $(r=0.90$, Table 3) for all soils, this relationship disappears if focusing on a single soil only. A relationship between the P-fractions considered as labile (EUF, Na$\mathrm{HCO}_{3}-\mathrm{P}_{\mathrm{i}}, \mathrm{CAL}-\mathrm{P}$ and MBP) is also indicated by a common cluster in the PCA (Figure 1).

CAL-P measurements separate COMP (+) and COMP $(-)$ more clearly than the $\mathrm{NaHCO}_{3}-\mathrm{P}_{\mathrm{i}}$-Fraction (Figure 2). This may be due the higher $\mathrm{pH}$ of COMP (+). In soils high in $\mathrm{pH}$, the acidic CAL solution ( $\mathrm{pH} 4.1$ ) may extract certain amounts of less plant available Ca-Phosphate.

Disturbance affected the labile $\mathrm{NaHCO}_{3}-\mathrm{P}_{\mathrm{o}}$ fractions mostly in the $\mathrm{COMP}(+)$ and MAN soils. As reported earlier, MBP is positively related to $\mathrm{NaHCO}_{3}-\mathrm{P}_{\mathrm{o}}$ fractions [41], but this was not the case in our study. In contrast, MBP could rather be related to $\mathrm{NaHCO}_{3}-\mathrm{P}_{\mathrm{i}}$ (Table 3), and this was also confirmed by the PCA analysis (Figure 


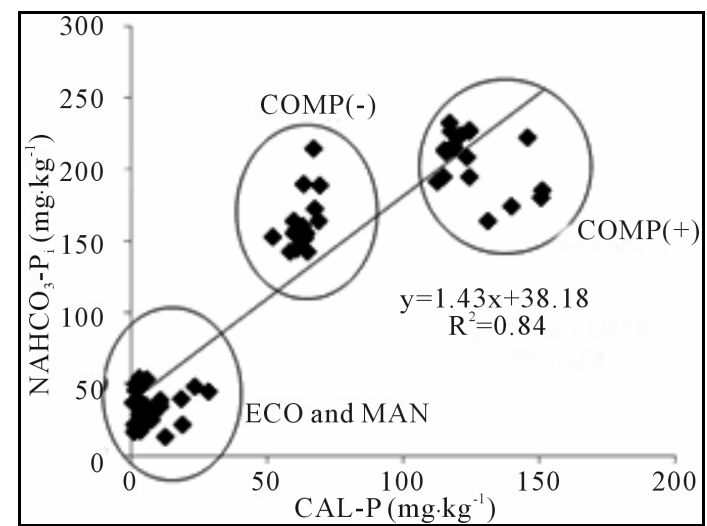

Figure 2. Regression between CAL-P and NaHCO3-Pi. Abbreviations: see Table 1.

1). This relation was also maintained if respective PCA's were done for each soil separately (not shown). Nevertheless, $\mathrm{NaHCO}_{3}-\mathrm{P}_{\mathrm{o}}$ could be closely related to P-ase indicating a participation in the microbial turnover (Figure 1).

Both $\operatorname{COMP}(+)$ and MAN soils have the highest $\mathrm{pH}$, and the highest $\mathrm{H}_{2} \mathrm{SO}_{4}-\mathrm{P}_{\mathrm{i}}$, fraction related to $\mathrm{Ca}$ bound Phosphates [28]. This can be a consequence of the slightly alkaline $\mathrm{pH}$ of both, compost residues and pig manure in COMP an MAN soils, respectively [54], and due to MAN soil natural properties. An apparent translocation from $\mathrm{NaOH}-\mathrm{P}_{\mathrm{o}}$ to $\mathrm{NaHCO}_{3}-\mathrm{P}_{\mathrm{o}}$ is visible for the $\operatorname{COMP}(+)$ soil indicating an increase of availability of $\mathrm{P}_{0}$. However the absolute decrease in $\mathrm{NaOH}-\mathrm{P}_{\mathrm{o}}$ cannot fully be explained by the increase in $\mathrm{NaHCO}_{3}-\mathrm{P}_{\mathrm{o}}$ or changes in any other fraction, indicating that further fractions are existing as a (preliminary) sink of originally organic P. Reference [55] proposed soil microbial residues as an intermediate sink for $\mathrm{N}$ which might also be true for $\mathrm{P}$. Higher P mobilization in the COMP $(+)$ compared to the other soils can be due to a higher $\mathrm{pH}$, lower resistance to mechanical disruption or more labile organic matter [56], lower aggregate size and higher friability [57], as a consequence of compost addition.

In MAN soil, on the other hand, labile $\mathrm{NaHCO}_{3}-\mathrm{P}_{\mathrm{i}}$ was apparently converted to $\mathrm{NaHCO}_{3}-\mathrm{P}_{\mathrm{o}}$. Microorganisms could have be grown and died between the time elapsed between incubation and determination, stimulated by soil rewetting by incubation, thus absorbing $\mathrm{P}_{\mathrm{i}}$ and releasing $\mathrm{P}$ as organic components recovered by $\mathrm{NaHCO}_{3}-\mathrm{P}_{\mathrm{o}}[55$, 58]. As microbes died and cell $P$ was reconverted to $P_{i}$ no change in MBP could be observed, but decrements of $\mathrm{MBC}$ and MBN as these elements cycles faster, as they are parts from no structural components of the cell. This conversion of labile $P_{i}$ to $P_{o}$ has not been observed for the other soils. This can be due to the nature and structure of the soil or due to the effects of the applied pig manure.

Regarding ECO soil, there was an increase of available CAL-P with $10 \mathrm{~d}$ as similarly observed with soil tillage
[59]. But this enhancement was not reflected by changes in the $\mathrm{P}$ fractionation, not even in the most available $\mathrm{NaHCO}_{3}-\mathrm{P}_{\mathrm{i}}$ fraction. The enhancement of $\mathrm{P}$ availability in the ECO soil may be attributed to an enhanced enzymatic activity after $10 \mathrm{~d}$ shaking. The COMP(-) soil was the less affected by disturbance. Only MBP was enhanced after $10 \mathrm{~d}$ shaking. This $\mathrm{P}$ uptake by microbes was not reflected in any change of the other P fractions. None of the other soils showed similar significant MBP changes.

In their meta study, [60] reported that a mean molar $\mathrm{C}: \mathrm{N}: \mathrm{P}$ ratio of $60: 7: 1$ for the soil microbial biomass can be found and that differences from this general ratio are less pronounce than similarities over a wide range of ecological properties. While the original $\operatorname{COMP}(+)$ soil is very similar to this ratio, the $\mathrm{C}: \mathrm{N}: \mathrm{P}$ ratio of the original COMP(-) soil indicates a much narrower relationship between $\mathrm{P}$ and the two other elements. In the original MAN and ECO soils, however, the ratios are much wider than reported by [60]. After incubation, however, the ratios decreased in all soils indicating a relative enrichment of soil microbial biomass in all treatments.

Our values for $\mathrm{MBP}$ and $\mathrm{MBP} / \mathrm{P}_{\mathrm{T}}$ in $\mathrm{COMP}(+)$ and COMP(-) were similar to those reported by [61] for German soils. MBP and MBC were negatively correlated (Table 3), and MBP can be related to the other $P_{i}$ forms, but $\mathrm{MBC}$ rather to $\mathrm{MBN}$ and $\mathrm{P}_{\mathrm{o}}$, as shown by PCA analysis. This can be explained by different distributions of $\mathrm{C}$ and $\mathrm{P}$ throughout the cell structures, thus, differing in cycling and microbial acquisition, or by the development of different microbial communities [62,63]. It is reported that environmental changes affect microbial communities more than microbial activity, and that microbial $\mathrm{P}$ is more susceptible to changes than $\mathrm{N}$ and $\mathrm{C}$, resulting in a faster microbial $P$ recycling $[62,64]$, but in our study microbial $\mathrm{P}$ was almost unaffected in spite of changes for microbial $\mathrm{C}$ and $\mathrm{N}$ in ECO soil and a redistribution of $\mathrm{P}$ fractions in $\operatorname{COMP}(+)$ soil. Almost all changes were in microbial $\mathrm{C}$ and $\mathrm{N}$ as well as in $\mathrm{P}_{\mathrm{o}}$ fractions, thus confirmed by a closer relationship between these variables as revealed by PCA analysis.

\section{Conclusion}

Short term soil disturbance had effects on labile organic $\mathrm{P}$ fractions of two of the four analyzed soils, but inorganic $P$ was rather unaffected. These changes can be associated to changes in the microbial biomass $\mathrm{C}$ and $\mathrm{N}$ as shown by PCA analysis, but microbial $\mathrm{P}$ was rather unaffected. In the compost amended COMP $(+)$ soil, there was an incorporation of $\mathrm{P}$ from the less available $\mathrm{NaOH}-\mathrm{P}_{\mathrm{o}}$ fractions into the more available $\mathrm{NaHCO}_{3}-\mathrm{P}_{\mathrm{o}}$ fraction. However, if taking all investigated soils and treatments into account, the effects of soil disturbance are limited and not consistent. Soils with high organic fertilization do not 
necessarily have higher organic $\mathrm{P}$ fractions and higher enzymatic activity than those without organic fertilization.

\section{Acknowledgements}

This work was supported by the Becas Chile Bicentenario Grant from CONICYT (Comisión Nacional de Investigación Científica y Tecnológica de Chile). We thank Mr. M. Kränzler, manager of the organic farm "Schönberger Hof", and Dr. M. Mokry, Agricultural Technology Centre (LTZ) in Karlsruhe-Durlach, for providing two of the investigated soils. The EUF analyses were performed by Dr. D. Horn, "EUF working group for the advancement of soil fertility and soil health" in Ochsenfurt, Germany. The ICP-OES P analyses were carried out in the State Institute of Agricultural Chemistry of the University of Hohenheim.

\section{REFERENCES}

[1] C. Pekrun, H.-P. Kaul and W. Claupein, "Soil Tillage for Sustainable Nutrient Management," In: A. Titi, Ed., Soil Tillage in Agroecosystems, Advances in Agroecology Series, Vol. 9, CRC Press, Boca Raton, 2002, http://dx.doi.org/10.1201/9781420040609.ch4

[2] B. Pezzarossa, M. Barbafieri, A. Benetti, G. Petruzzelli, M. Mazzoncini, E. Bonari and M. Pagliai, "Effects of Conventional and Alternative Management Systems on Soil Phosphorus Content, Soil Structure, and Corn Yield," Communications in Soil Science and Plant Analysis, Vol. 261, No. 17-18, 1995, pp. 2869-2885.

http://dx.doi.org/10.1080/00103629509369494

[3] Z. R. Zheng, R. Simard, J. Lafond and L. E. Parent, "Pathways of Soil Phosphorus Transformations after 8 Years of Cultivation under Contrasting Cropping Practices," Soil Science Society of American Journal, Vol. 66, No. 3, 2002, pp. 999-1007. http://dx.doi.org/10.2136/sssaj2002.0999

[4] S. Daroub, F. Pierce and B. Ellis, "Phosphorus Fractions and Fate of Phosphorus-33 in Soils under Plowing and No-Tillage," Soil Science Society of American Journal, Vol. 64, No. 1, 2000, pp. 170-176. http://dx.doi.org/10.2136/sssaj2000.641170x

[5] Z. Zheng, J. A. MacLeod and J. Lafond, "Phosphorus Status of a Humic Cryaquept Profile in a Frigid Continental Climate as Influenced by Cropping Practices," Biology and Fertility of Soils, Vol. 39, No. 6, 2004, pp. 467473. http://dx.doi.org/10.1007/s00374-004-0735-5

[6] L. M. Zibilske and J. M. Bradford, "Tillage Effects on Phosphorus Mineralization and Microbial Activity," Soil Science, Vol. 168, No. 10, 2003, pp. 677-685. http://dx.doi.org/10.1097/01.ss.0000095141.68539.c7

[7] Y. Redel, R. Rubio, J. Rouanet and F. Borie, "Phosphorus Bioavailability Affected by Tillage and Crop Rotation on a Chilean Volcanic Derived Ultisol," Geoderma, Vol. 139, No. 3-4, 2007, pp. 388-396.

http://dx.doi.org/10.1016/j.geoderma.2007.02.018
[8] Y. Redel, M. Escudey, M. Alvear, J. Conrad and F. Borie, "Effects of Tillage and Crop Rotation on Chemical Phosphorus Forms and Some Related Biological Activities in a Chilean Ultisol," Soil Use and Management, Vol. 27, No. 2, 2011, pp. 221-228. http://dx.doi.org/10.1111/j.1475-2743.2011.00334.x

[9] R. G. Joergensen and M. Raubuch, "Adenylate Energy Charge and ATP-to-Microbial Biomass C Ratio in Soils Differing in the Intensity of Disturbance," Soil Biology and Biochemistry, Vol. 35, No. 9, 2003, pp. 1161-1164. http://dx.doi.org/10.1016/S0038-0717(03)00150-0

[10] N. Morris, P. Miller, J. Orson and R. J. Froud-Williams, "The Adoption of Non-Inversion Tillage Systems in the United Kingdom and the Agronomic Impact on Soil, Crops and the Environment-A Review," Soil Tillage Research, Vol. 108, No. 1-2, 2010, pp. 1-15. http://dx.doi.org/10.1016/j.still.2010.03.004

[11] J. Balesdent, C. Chenu and M. Balabane, "Relationship of Soil Organic Matter Dynamics to Physical Protection and Tillage," Soil Tillage Research, Vol. 53, No. 3-4, 2000, pp. 215-230. http://dx.doi.org/10.1016/S0167-1987(99)00107-5

[12] T. Müller, K. Thorup-Kristensen, J. Magid, L. S. Jensen and S. Hansen, "Catch Crops Affect Nitrogen Dynamic in Organic Farming Systems without Livestock HusbandrySimulations with the DAISY Model," Ecological Modelling, Vol. 191, No. 3-4, 2006 pp. 538-544. http://dx.doi.org/10.1016/j.ecolmodel.2005.05.026

[13] S. O. Ojeniyi, "Nutrient Availability and Maize Yield under Reduced Tillage Practices," Soil Tillage Research, Vol. 26, No. 1, 1993, pp. 89-92. http://dx.doi.org/10.1016/0167-1987(93)90089-8

[14] J. Raupp, C. Letalik and F. Haunz, "Nitrate Release under a Silage Maize Crop after Turning in a Clover-Grass Crop in the Spring," Journal of Agronomy and Crop Sciences, Vol. 166, No. 3, 2001, pp. 181-190. http://dx.doi.org/10.1111/j.1439-037X.1991.tb00902.x

[15] C. W. Watts, S. Eich and A. R. Dexter, "Effects of Mechanical Energy Inputs on Soil Respiration at the Aggregate and Field Scale," Soil Tillage Research, Vol. 53, No. 3-4, 2000, pp. 231-243.

[16] C. W. Watts, P. D. Hallett and A. R. Dexter, "Effects of Stresses and Strains on Soil Respiration," In: J. Berthelin, P. M. Huang, J. M. Bollag and F. Andreux, Eds., The Effect of Mineral-Organic-Microorganism Interactions on Soil and Freshwater Environments, Plenum Press, New York, 1999, pp. 305-316. http://dx.doi.org/10.1007/978-1-4615-4683-2 33

[17] A. Wright, "Phosphorus Sequestration in Soil Aggregates after Long-Term Tillage and Cropping," Soil Tillage Research, Vol. 103, No. 2, 2009, pp. 406-411. http://dx.doi.org/10.1016/j.still.2008.12.008

[18] H. Omidi, Z. Tahmasebib, H. Torabic and M. Miransaric, "Soil Enzymatic Activities and Available P and Zn as Affected by Tillage Practices, Canola (Brassica napus L.) Cultivars and Planting Dates," European Journal of Soil Biology, Vol. 44, No. 4, 2008, pp. 443-450. http://dx.doi.org/10.1016/j.ejsobi.2008.05.002

[19] W. Kingery, C. Wood and J. Williams, "Tillage and Amend- 
ment Effects on Soil Carbon and Nitrogen Mineralization and Phosphorus Release," Soil Tillage Research, Vol. 37, No. 4, 1996, pp. 239-250. http://dx.doi.org/10.1016/0167-1987(96)01009-4

[20] B. Beavers, Z. Liu, M. Cox, W. Kingery, G. Brink, P. Gerard and K. McGregor, "Phosphorus Dynamics in Two Poultry-Litter Amended Soils of Mississippi under Three Management Systems," Pedosphere, Vol. 20, No. 2, 2010, pp. 217-228.

http://dx.doi.org/10.1016/S1002-0160(10)60009-4

[21] O. K. Borggaard, B. Raben-Lange, A. L. Gimsing and B. W. Strobel, "Influence of Humic Substances on Phosphate Adsorption by Aluminium and Iron Oxides," Geoderma, Vol. 127, No. 3-4, 2005, pp. 270-279. http://dx.doi.org/10.1016/j.geoderma.2004.12.011

[22] C. Singh and A. Amberger, "Humic Substances in Straw Compost with Rock Phosphate," Biological Wastes, Vol. 31, No. 3, 1990, pp. 165-174. http://dx.doi.org/10.1016/0269-7483(90)90156-M

[23] C. W. Watts and A. R. Dexter, "The Influence of Organic Matter in Reducing the Destabilization of Soil by Simulated Tillage," Soil Tillage Research, Vol. 42, No. 4, 1997, pp. 253-275.

http://dx.doi.org/10.1016/S0167-1987(97)00009-3

[24] B. Hansen, H. Alrøe and E. Kristensen, "Review: Approaches to Assess the Environmental Impact of Organic Farming with Particular Regard to Denmark," Agriculture, Ecosystems and Environment, Vol. 83, No. 1-2, 2001, pp. 11-26. http://dx.doi.org/10.1016/S0167-8809(00)00257-7

[25] F. Wald, C. Pekrun and W. Claupein, "Einfluss der Bodenbearbeitung nach Mehrjährigem Leguminosen-Grasgemengeanbau auf die N-Mineralisierung unter den Bedingungen des Organischen Landbaus," In: H. J. Reents, Ed., Beiträge zur 6. Wissenschaftstagung zum Ökologischen Landbau "Von Leit-linien zu Leit-bildern", Köster, Berlin, 2001, pp. 425-428.

[26] H. Hedley, J. Steward and B. Chauhuan, "Changes in Organic and Inorganic Soil Phosphorus Fractions Induced by Cultivation Practices and by Laboratory Incubations," Soil Science Society of American Journal, Vol. 46, No. 5, 1982, pp. 970-976.

http://dx.doi.org/10.2136/sssaj1982.03615995004600050 $\underline{017 \mathrm{x}}$

[27] A. Cross and W. Schlesinger, "A Literature Review and Evaluation of the Hedley Fractionation: Applications to the Biogeochemical Cycle of Soil Phosphorus in Natural Ecosystems," Geoderma, Vol. 64, No. 3-4, 1995, pp. 197214. http://dx.doi.org/10.1016/0016-7061(94)00023-4

[28] A. Johnson, J. Frizano and D. Vann, "Biogeochemical Implications of Labile Phosphorus in Forest Soils Determined by the Hedley Fractionation Procedure," Oecologia, Vol. 135, 2003 pp. 487-499.

[29] B. Turner, B. Cade-Menun, L. Condron and S. Newman, "Extraction of Soil Organic Phosphorus," Talanta, Vol. 66, No. 2, 2005, pp. 294-306. http://dx.doi.org/10.1016/j.talanta.2004.11.012

[30] M. Herlihy and D. McGrath, "Phosphorus Fractions and Adsorption Characteristics in Grassland Soils of Varied Soil Phosphorus Status," Nutrient Cycling in Agroecosys- tems, Vol. 77, No. 1, 2007, pp. 15-27. http://dx.doi.org/10.1007/s10705-006-6687-4

[31] P. Brookes, D. Powlson and D. Jenkinson, "Phosphorus in the Soil Microbial Biomass," Soil Biology and Biochemistry, Vol. 16, No. 2, 1984, pp. 169-175. http://dx.doi.org/10.1016/0038-0717(84)90108-1

[32] D. E. Patterson, W. C. Chamen and C. D. Richardson, "Long-Term Tillage Experiments with Tillage Systems to Improve the Economy of Cultivations for Cereals," Journal of Agricultural Engineering Research, Vol. 25, No. 1, 1980 , p. L-36.

http://dx.doi.org/10.1016/0021-8634(80)90044-X

[33] E. D. Vance, P. C. Brookes and D. S. Jenkinson, “An Extraction Method for Measuring Soil Microbial Biomass C," Soil Biology and Biochemistry, Vol. 19, No. 6, 1987, pp. 703-707. http://dx.doi.org/10.1016/0038-0717(87)90052-6

[34] J. Wu, R.G. Joergensen, B. Pommerening, R. Chaussod and P. Brookes, "Measurement of Soil Microbial Biomass C by Fumigation-Extraction-An Automated Procedure," Soil Biology and Biochemistry, Vol. 22, No. 8, 1990, pp. 167-169.

http://dx.doi.org/10.1016/0038-0717(90)90046-3

[35] R. G Joergensen, "The Fumigation-Extraction Method to Estimate Soil Microbial Biomass: Calibration of the $\mathrm{k}_{\mathrm{EC}}$ Value," Soil Biology and Biochemistry, Vol. 28, No. 1, 1996, pp. 25-31. http://dx.doi.org/10.1016/0038-0717(95)00102-6

[36] R. G. Joergensen and T. Mueller, "The Fumigation-Extraction Method to Estimate Soil Microbial Biomass: Calibration of the $k_{\mathrm{EN}}$ Value," Soil Biology and Biochemistry, Vol. 28, No. 1, 1996, pp. 33-37. http://dx.doi.org/10.1016/0038-0717(95)00101-8

[37] H. Tiessen and J. O. Moir, "Characterization of Available P by Sequential Extraction," In: M. R. Carter, Ed., Soil Sampling and Methods of Analysis, Lewis Publishers, Boca Raton, 1993, pp. 75-86.

[38] J. Murphy and J. P. Riley, "A Modified Single Solution Method for the Determination of Phosphate in Natural Waters," Analytica Chimica Acta, Vol. 27, No. 1, 1962, pp. 31-36. http://dx.doi.org/10.1016/S0003-2670(00)88444-5

[39] VDLUFA, "Methodenbuch Band VII Umweltanalytik," 1. Auflage, 1. Teillieferung. VDLUFA-Verlag, Darmstadt, 1996.

[40] S. Heinze, M. Oltmanns, R. G. Joergensen and J. Raupp, "Changes in Microbial Biomass Indices after 10 Years of Farmyard Manure and Vegetal Fertilizer Application to a Sandy Soil under Organic Management," Plant and Soil, Vol. 343, No. 1-2, 2011, pp. 221-234. http://dx.doi.org/10.1007/s11104-010-0712-8

[41] K. S. Khan and R. G. Joergensen, "Changes in Microbial Biomass and P Fractions in Biogenic Household Waste Compost Amended with Inorganic P Fertilizers," Bioresources Technology, Vol. 100, No. 1, 2009, pp. 303-309. http://dx.doi.org/10.1016/j.biortech.2008.06.002

[42] VDLUFA, "Methodenbuch Band I. Die Untersuchung der Böden," 4. Auflage, 1. und 2. Teillieferung. VDLUFAVerlag, Darmstadt, 1997. 
[43] R. Rubio, E. Moraga and F. Borie, "Acid Phosphatase Activity and Vesicular-Arbuscular Infection Associated with Roots of Four Wheat Cultivars," Journal of Plant Nutrition, Vol. 13, No. 5, 1990, pp. 585-598. http://dx.doi.org/10.1080/01904169009364102

[44] Y. Redel, R. Rubio, R. Godoy and F. Borie, "Phosphorus Fractions and Phosphatase Activity in an Andisol under Different Forest Ecosystems," Geoderma, Vol. 145, No. 34, 2008, pp. 216-221. http://dx.doi.org/10.1016/j.geoderma.2008.03.007

[45] K. Németh, "Recent Advances in EUF Research (19801983)," Plant and Soil, Vol. 83, No. 1, 1985, pp. 1-19. http://dx.doi.org/10.1007/BF02182711

[46] D. Steffens, T. Leppin, N. Luschin-Ebengreuth, Z. Yang and S. Schubert, "Organic Soil Phosphorus Considerably Contributes to Plant Nutrition But Is Neglected by Routine Soil-Testing Methods," Journal of. Plant Nutrition and Soil Science, Vol. 173, No. 5, 2010, pp. 765-771. http://dx.doi.org/10.1002/jpln.201000079

[47] SAS/STAT, "SAS/STAT Users Guide: Statistics," Version 6, 4th Edition, SAS Institute, Cary, 1990.

[48] M. Malik, K. Khan, P. Marschner and S. Ali, "Organic Amendments Differ in Their Effect on Microbial Biomass and Activity and on P Pools in Alkaline Soils," Biology and Fertility of Soils, Vol. 49, No. 4, 2013, pp. 415-425. http://dx.doi.org/10.1007/s00374-012-0738-6

[49] M. Malik, P. Marschner, K. Khan and S. Ali, "Addition of Organic and Inorganic P Sources to Soil-Effects on P Pools and Microorganisms," Soil Biology and Biochemistry, Vol. 49, No. 1, 2012, pp. 106-113. http://dx.doi.org/10.1016/j.soilbio.2012.02.013

[50] A. Y. Lopez-Contreras, I. Hernandez-Valencia and D. Lopez-Hernandez, "Fractionation of Soil Phosphorus in Organic Amended Farms Located on Savanna Sandy Soils of Venezuelan Amazonian," Biology and Fertility of Soils, Vol. 43, No. 6, 2007, pp. 771-777.

http://dx.doi.org/10.1007/s00374-006-0162-x

[51] M. Park, A. Singvilay, W. Shin, E. Kima, J. Chung and T. Saa, "Effects of Long-Term Compost and Fertilizer Application on Soil Phosphorus Status under Paddy Cropping System," Communications in Soil Science and Plant Analysis, Vol. 35, No.11-12, 2004, pp. 1635-1644. http://dx.doi.org/10.1081/CSS-120038559

[52] X. H. Li, X. Z. Han, H. B. Li, C. Song, J. Yan and Y. Liang, "Soil Chemical and Biological Properties Affected by 21-Year Application of Composted Manure with Chemical Fertilizers in a Chinese Mollisol," Canadian Journal of Soil Science, Vol. 92, No. 3, 2012, pp. 419-428. http://dx.doi.org/10.4141/cjss2010-046

[53] C. Welsh, M. Tenuta, D. N. Flaten, R. Thiessen-Martens and M. H. Entz, "High Yielding Organic Crop Management Decreases Plant-Available But Not Recalcitrant Soil Phosphorus," Agronomy Journal, Vol. 101, No. 5, 2009, pp. 1027-1035. http://dx.doi.org/10.2134/agronj2009.0043

[54] F. X. Zhu, W. P. Wang, C. L. Hong, M. G. Feng, Z. Y. Xue, X. Y. Chen, Y. L. Yao and M. Yu, "Rapid Produc- tion of Maggots as Feed Supplement and Organic Fertilizer by the Two-Stage Composting of Pig Manure," Bioresource Technology, Vol. 116, No. 1, 2012, pp. 485-491. http://dx.doi.org/10.1016/j.biortech.2012.04.008

[55] T. Mueller, J. Magid, L. S. Jensen, H. Svendsen and N. E. Nielsen, "Soil C and N Turnover after Incorporation of Chopped Maize, Barley Straw and Blue Grass in the Field: Evaluation of the DAISY Soil-Organic-Matter Submodel," Ecological Modelling, Vol. 111, No. 1, 1998, pp. 115. http://dx.doi.org/10.1016/S0304-3800(98)00094-5

[56] W. Cookson, D. Murphy and M. Roper, "Characterizing the Relationships between Soil Organic Matter Components and Microbial Function and Composition along a Tillage Disturbance Gradient," Soil Biology and Biochemistry, Vol. 40, No. 3, 2008, pp. 763-777. http://dx.doi.org/10.1016/j.soilbio.2007.10.011

[57] J. Miller, B. W Beasley, C. F Drury and B. J. Zebarth, "Long-Term Effect of Fresh and Composted Cattle Manure on the Size and Nutrient Composition of Dry-Sieved Soil Aggregates," Canadian Journal of Soil Science, Vol. 92, No. 6, 2012, pp. 865-882. http://dx.doi.org/10.4141/cjss2011-107

[58] B. Turner, J. Driessen, P. Haygarth and I. Mckelvie, "Potential Contribution of Lysed Bacterial Cells to Phosphorus Solubilization in Two Rewetted Australian Pasture Soils," Soil Biology and Biochemistry, Vol. 35, No. 1, 2003, pp. 187-189. http://dx.doi.org/10.1016/S0038-0717(02)00244-4

[59] B. Nguyen and P. Marschner, "Effect of Drying and Rewetting on Phosphorus Transformations in Red Brown Soils with Different Soil Organic Matter Content," Soil Biology and Biochemistry, Vol. 37, No. 8, 2005, pp. 15731576. http://dx.doi.org/10.1016/j.soilbio.2005.01.015

[60] C. Cleveland and D. Liptzin, "C:N:P Stoichiometry in Soil: Is There a 'Redfield Ratio' for the Microbial Biomass?" Biogeochemistry, Vol. 85, No. 3, 2007, pp. 235252. http://dx.doi.org/10.1007/s10533-007-9132-0

[61] K. S. Khan and R. G. Joergensen, "Relationships between $P$ Fractions and the Microbial Biomass in Soils under Different Land Use Management," Geoderma, Vol. 173174, No. 1, 2012, pp. 274-281. http://dx.doi.org/10.1016/j.geoderma.2011.12.022

[62] D. Achat, C. Morel, M. Bakker, L. Augusto, S. Pellerin, A. Gallet-Budynek and M. Gonzalez, "Assessing Turnover of Microbial Biomass Phosphorus: Combination of an Isotopic Dilution Method with a Mass Balance Model," Soil Biology and Biochemistry, Vol. 42, No. 12, 2010, pp. 2231-2240.http://dx.doi.org/10.1016/j.soilbio.2010.08.023

[63] E. Bünemann B. Prusisz and K. Ehlers, "Chapter 2. Characterization of Phosphorus Forms in Soil Microorganisms," In: E. K. Bünemann, A. Oberson and E. Frossard, Eds., Phosphorus in Action, Springer-Verlag, Berlin, 2011, pp. 37-57.

[64] J. DeForest and L. Scott “Available Organic Soil Phosphorus Has an Important Influence on Microbial Community Composition," Soil Science Society of American Journal, Vol. 74, No. 6, 2010, pp. 2059-2066. http://dx.doi.org/10.2136/sssaj2009.0426 